\title{
Prolonged High Temperature Exposure and Daily Light Integral Impact Growth and Flowering of Five Herbaceous Ornamental Species
}

\author{
Ryan M. Warner ${ }^{1}$ and John. E. Erwin ${ }^{2}$ \\ Department of Horticultural Science, University of Minnesota, 305 Alderman Hall, 1970 Folwell \\ Avenue, Saint Paul, MN 55108
}

\begin{abstract}
AdDitional INDEX wORDs. heat stress, flower initiation, flower development, flower size, Antirrhinum majus, Calendula officinalis, Impatiens wallerana, Mimulus $\times$ hybridus, Torenia fournieri
\end{abstract}

\begin{abstract}
Aвstract. Flowering of many herbaceous ornamentals is reduced or eliminated under high temperatures. On warm, sunny days, greenhouse growers often cover crops with light-reducing screening materials to reduce air and plant temperature. However, low irradiance can also reduce flowering on many species. To examine the impacts of temperature and irradiance on herbaceous ornamental flowering and to select a model to study high temperature-reduced flowering, Antirrhinum majus L. (snapdragon) 'Rocket Rose', Calendula officinalis L. (calendula) 'Calypso Orange', Impatiens wallerana Hook.f. (impatiens) 'Super Elfin White', Mimulus xhybridus Hort. ex Siebert \& Voss (mimulus) 'Mystic Yellow', and Torenia fournieri Linden ex E. Fourn (torenia) 'Clown Burgundy' were grown at constant $32 \pm 1$ ${ }^{\circ} \mathrm{C}$ or $20 \pm 1.5^{\circ} \mathrm{C}$ under a 16-hour photoperiod with daily light integrals (DLI) of $10.5,17.5$, or $21.8 \mathrm{~mol}^{\cdot} \cdot \mathrm{m}^{-2} \cdot \mathrm{d}^{-1}$. Flower bud number per plant (all flower buds $\geq 1 \mathrm{~mm}$ in length when the first flower opened) of all species was lower at 32 than $20{ }^{\circ} \mathrm{C}$. Reduction in flower bud number per plant at 32 compared to $20{ }^{\circ} \mathrm{C}$ varied from $30 \%$ (impatiens) to $95 \%$ (torenia) under a DLI of $10.5 \mathrm{~mol} \cdot \mathrm{m}^{-2} \cdot \mathrm{d}^{-1}$. Flower diameter of all species except snapdragon was less at 32 than $20{ }^{\circ} \mathrm{C}$. Decreasing DLI from 21.8 to $10.5 \mathrm{~mol} \cdot \mathrm{m}^{-2} \cdot \mathrm{d}^{-1}$ decreased flower diameter of all species except snapdragon. Calendula, impatiens, and torenia leaf number below the first flower was greater at 32 than $20^{\circ} \mathrm{C}$, regardless of DLI. Increasing DLI from 10.5 to $17.5 \mathrm{~mol} \cdot \mathrm{m}^{-2} \cdot \mathrm{d}^{-1}$ increased shoot dry mass gain rate of all species, regardless of temperature. Further increasing DLI from 17.5 to $21.8 \mathrm{~mol} \cdot \mathrm{m}^{-2 \cdot} \cdot \mathrm{d}^{-1}$ at $20^{\circ} \mathrm{C}$ increased shoot dry mass gain rate of all species except snapdragon and mimulus, indicating that these species may be light saturated below $21.8 \mathrm{~mol} \cdot \mathrm{m}^{-2} \cdot \mathrm{d}^{-1}$. Under DLIs of 17.5 and 21.8 $\mathrm{mol} \cdot \mathrm{m}^{-2 \cdot} \cdot \mathrm{d}^{-1}$ shoot dry mass gain rate was lower at 32 than $20^{\circ} \mathrm{C}$ for all species except torenia. Torenia shoot dry mass gain rate was $129 \mathrm{mg} \cdot \mathrm{d}^{-1}$ at $20^{\circ} \mathrm{C}$ compared to $252 \mathrm{mg} \cdot \mathrm{d}^{-1}$ at $32{ }^{\circ} \mathrm{C}$ under a DLI of $17.5 \mathrm{~mol}^{\circ} \cdot \mathrm{m}^{-2} \cdot \mathrm{d}^{-1}$. We suggest torenia may be a good model to study the basis for inhibition of flowering under high temperatures as flowering, but not dry mass gain, was reduced at $32^{\circ} \mathrm{C}$.
\end{abstract}

High temperatures negatively impact flower induction (Schwabe, 1985), flower development (Abdul-Baki, 1991) and flower size (Niu et al., 2000). For example, night temperatures above $30^{\circ} \mathrm{C}$ reduce flower number per inflorescence of Kalanchoe blossfeldiana Poelln. (kalanchoe) (Schwabe, 1985). Similarly, increasing the duration of a high temperature $\left(30 / 26^{\circ} \mathrm{C}\right.$ day/night $)$ exposure reduced floret number formed on Chrysanthemum xmoriflorum Ramat. (chrysanthemum) 'Orange Bowl' flowers (Whealy et al., 1987). Differences in high temperature sensitivity among cultivars or genotypes have been noted for many species. For example, high temperature-induced $\left(32 / 28{ }^{\circ} \mathrm{C}\right.$ compared to $22 / 18^{\circ} \mathrm{C}$ day/night) reduction in Lycopersicon esculentum Mill. (tomato) flower number per inflorescence varied across genotypes (Warner and Erwin, 2001a).

The widely observed physiological disorder termed "heat delay" results from high temperatures delaying flower initiation (Whealy et al., 1987). Temperatures that result in "heat delay"

Received for publication 8 Aug. 2004. Accepted for publication 27 Nov. 2004. The authors wish to thank Pan American Seed for donation of seed. Additionally, the authors wish to thank the Richard E. Widmer Teaching and Research Fund, the Minnesota Commercial Flower Growers Association, the Minnesota Nursery and Landscape Association, the Ohio Florists' Association, and the Minnesota Agricultural Experiment Station for financial support.

${ }^{1}$ Former Graduate Research Assistant. Current address: Dept. of Horticulture, Michigan State University, A234 Plant and Soil Sciences, East Lansing, MI 48824.

${ }^{2}$ Associate Professor; to whom reprint requests should be addressed. E-mail address: erwin001@umn.edu vary across species. Night temperatures $\geq 25^{\circ} \mathrm{C}$ delay chrysanthemum flower initiation (de Lint and Heij, 1987; Whealy et al., 1987; Wilkins et al., 1990). This response occurred irrespective of day temperatures up to $25{ }^{\circ} \mathrm{C}$ (the highest day temperature studied; de Lint and Heij, 1987). Schlumbergera truncata (Haw.) Moran (thanksgiving cactus) flower initiation was inhibited when day or night temperature was $30^{\circ} \mathrm{C}$ (9-h photoperiod), or when average daily temperature was $\geq 25^{\circ} \mathrm{C}$ (Erwin et al., 1990). In contrast, increasing night temperature from 12 to $30^{\circ} \mathrm{C}$ increased the percentage of Pharbitis nil Chois. (japanese morning glory) plants flowering from 0 to $100 \%\left(24^{\circ} \mathrm{C}\right.$ day temperature) (Reese and Erwin, 1997).

High temperatures can also inhibit flower development (AbdulBaki, 1991), including pollen development (Pressman et al., 2002). Temperatures that negatively impact floral development vary across species. Capsicum annиum L. (pepper) flower abscission (associated with floral developmental arrest) is high when day temperature is 32 to $38{ }^{\circ} \mathrm{C}$ or when night temperature is $>21^{\circ} \mathrm{C}$ (Rylski, 1986). Aloni et al. (1991) reported that increasing day/ night temperatures from $25 / 18^{\circ} \mathrm{C}$ to $35 / 25^{\circ} \mathrm{C}$ did not affect pepper flower bud growth after $6 \mathrm{~h}$ of heat stress. However, flower bud growth ceased after $24 \mathrm{~h}$ at $35 / 25^{\circ} \mathrm{C}$ and flower diameter decreased from 24 to $48 \mathrm{~h}$ at $35 / 25^{\circ} \mathrm{C}$. After a $5-\mathrm{d} 35 / 25^{\circ} \mathrm{C}$ exposure, $~ 35 \%$ of flower buds abscised from plants with developing fruit, while no flower buds abscised if plants did not have developing fruit, suggesting competition for photoassimilates between developing flowers and developing fruits. High night temperature increased 
flower abscission, as a $5-\mathrm{d} 25 / 35^{\circ} \mathrm{C}$ exposure resulted in $100 \%$ and $50 \%$ flower bud abscission on plants with and without developing fruits, respectively. Similarly, Brassica oleracea $\mathrm{L}$. var. botrytis L. (broccoli) inflorescence development is disrupted by temperatures above $30^{\circ} \mathrm{C}$ (Bjorkman and Pearson, 1998; Carr and Irish, 1997). Bjorkman and Pearson (1998) reported that exposure to $35^{\circ} \mathrm{C}$ for $7-10 \mathrm{~d}$ when the inflorescence was less than $5 \mathrm{~mm}$ in diameter disrupted inflorescence development; the inflorescence was not sensitive to the same high temperature exposures when $5-10 \mathrm{~mm}$ in diameter or larger. In contrast to the heat sensitivity of young flower buds in broccoli, Phaseolus vulgaris L. (bean) flower buds $<6 \mathrm{~d}$ before anthesis were more heat sensitive than younger reproductive organs, averaging $79 \%$ abscission following a 1-3 d exposure to $35^{\circ} \mathrm{C}$ compared to $53 \%$ abscission of buds $>8 \mathrm{~d}$ before anthesis (Monterosso and Wien, 1990).

High temperatures also reduce flower size. For example, Viola $\times$ wittrockiana Gams. (pansy) flower size decreased linearly as temperature increased from 9 to $31^{\circ} \mathrm{C}$ (Pearson et al., 1995) or from 16 to $26^{\circ} \mathrm{C}$ (Niu et al. 2000). Similarly, Pelargonium $\times$ hortorum Bailey (geranium) flower diameter decreased as temperature increased from 15 to $32{ }^{\circ} \mathrm{C}$ (Armitage et al., 1981).

In addition to high temperatures, the total amount of light received by a plant in a day, the DLI, can also impact flower initiation (Warner and Erwin, 2003), flower development (Calvert, 1969), and dry mass gain (Karlsson and Heins, 1992). In general, plant dry mass increases as DLI increases (Fierro et al., 1994; Kitaya et al., 1998) up to a light saturation point. For example, Lactuca sativa L. (lettuce) 'Summer-green' dry mass increased linearly as DLI increased from 5.8 to $17.3 \mathrm{~mol} \cdot \mathrm{m}^{-2} \cdot \mathrm{d}^{-1}$ (the highest DLI examined; Kitaya et al., 1998).

Increasing DLI can increase flower bud number per plant (Mortensen and Moe, 1995; Serek, 1991; Warner and Erwin, 2003). For example, increasing DLI from 6.7 to $8.9 \mathrm{~mol} \cdot \mathrm{m}^{-2} \cdot \mathrm{d}^{-1}$ increased Hibiscus radiatus Cav. flower bud number at first flower from 7 to 10 buds (Warner and Erwin, 2003). Further increasing DLI did not impact flower bud number. Similarly, increasing DLI from 5.5 to $8.4 \mathrm{~mol} \cdot \mathrm{m}^{-2} \cdot \mathrm{d}^{-1}$ increased Rosa $\mathrm{L}$. (miniature rose) 'Rubino' flower number from 10 to 18 flowers and buds per plant (Mortensen and Moe, 1995).

Increasing DLI can also hasten flowering developmentally (i.e., reduce leaf number below the first flower) in some species. For example, increasing DLI from 8.3 to $25.5 \mathrm{~mol} \cdot \mathrm{m}^{-2} \cdot \mathrm{d}^{-1}$ decreased Hibiscus cisplatinus St-Hil. leaf number below the first flower from 26 to 18 leaves (Warner and Erwin, 2003). Increasing DLI also reduced leaf number below the first flower of several annual herbaceous ornamental species, including Cosmos bipinnatus Cav. Ann. (cosmos) 'White Sensation', Nicotiana alata Link \& Otto (flowering tobacco) 'Domino White', and Silene armeria L. (catchfly) (Erwin and Warner, 2002).

As described above, high temperature and/or low irradiance can reduce crop quality by reducing plant mass at flowering, flower size, and flower number. The objectives of this study were to 1) characterize the impact of high temperature exposure and DLI on growth and flowering characteristics of five herbaceous ornamental species; 2) determine whether reductions in flowering of these species were associated with high temperature, DLI, or interaction between temperature and DLI; and 3) determine whether there is an association between flowering reduction and dry mass gain rate. A further objective was to identify a species as a potential model for studying high temperature-induced flowering inhibition.

\section{Materials and Methods}

Antirrhinum majus 'Rocket Rose', Calendula officinalis 'Calypso Orange', Impatiens wallerana 'Super Elfin White', Mimulus xhybridus 'Mystic Yellow', and Torenia fournieri 'Clown Burgundy' seeds were sown on 26 Feb. in 25 -mL cells in a soilless medium (Germination Mix; Strong-Lite Horticultural Products, Pine Bluff, Ark.) and placed under intermittent mist (6-s mist every $10 \mathrm{~min}$ from $0800-2000 \mathrm{HR})$ at $23 \pm 1{ }^{\circ} \mathrm{C}(24-\mathrm{h}$ mean $\pm \mathrm{SE})$ air temperature until the cotyledons were parallel to the media surface. Seedlings were then transplanted into $450-\mathrm{mL}$ pots in a soilless medium (Universal Mix; Strong-Lite Horticultural Products) and placed in a greenhouse at $18 \pm 1.5^{\circ} \mathrm{C}$ air temperature under a 14-h photoperiod provided by ambient irradiance and high-pressure sodium lamps (0600-2000 HR; Lucolux LU400; General Electric, Cleveland), until treatments were initiated (when seedlings had unfolded two true leaves).

On 22 Mar. plants were placed under one of two temperatures (constant $20 \pm 1.5^{\circ} \mathrm{C}$ or $32 \pm 1{ }^{\circ} \mathrm{C}$ ) and under one of three irradiance levels within each temperature treatment: $60 \%$ ambient (St. Paul, Minn.; $45^{\circ} \mathrm{N}$ ) irradiance (using a $40 \%$ light reduction material), ambient irradiance, or ambient plus $75 \mu \mathrm{mol} \cdot \mathrm{m}^{-2} \cdot \mathrm{s}^{-1}$ [all supplemental irradiance provided from 0600-2200 HR by highpressure sodium lamps (Lucolux LU400). To prevent confounding effects of photoperiod and light quality on flower induction, a low supplemental irradiance level $\left(10 \mu \mathrm{mol} \cdot \mathrm{m}^{-2} \cdot \mathrm{s}^{-1}\right)$ was provided to the $60 \%$ ambient and ambient irradiance treatments to maintain the same photoperiod and similar light spectra. The irradiance treatments resulted in average DLIs of $10.5 \pm 0.7,17.5 \pm 1.8$, and $21.8 \pm 1.8 \mathrm{~mol} \cdot \mathrm{m}^{-2} \cdot \mathrm{d}^{-1}$. Ambient irradiance and temperature were measured every $60 \mathrm{~s}$ with a quantum sensor (QSO-SUN; Apogee Instruments, Logan, Utah) and a thermocouple (Type E Wire chromega/constantan; Omega Engineering, Stamford, Conn.), respectively, connected to a datalogger (CR10; Campbell Scientific, Logan, Utah) and averaged every hour. Hourly averages were used to calculate ambient DLI. DLIs for the $60 \%$ ambient and ambient plus $75 \mu \mathrm{mol} \cdot \mathrm{m}^{-2} \cdot \mathrm{s}^{-1}$ were calculated from the ambient DLI. Plants were fertilized at each watering with $14.3 \mathrm{~mm} \mathrm{~N}, 0.72$ mм P, $6.5 \mathrm{~mm} \mathrm{~K}, 1.67 \mathrm{~mm} \mathrm{Ca}, 1.1 \mathrm{~mm} \mathrm{Mg}$, plus trace amounts of micronutrients (Miracle-Gro Excel 15-2.2-12.5 Cal-Mag; Scott's Co., Marysville, Ohio). Plants were watered/fertilized until the solution ran out the bottom of the pot to eliminate fertility differences due to differences in watering practices between temperature/lighting treatments.

The experiment employed a split-plot statistical design with temperature as the main plot and irradiance as the subplot with species completely randomized within each subplot. Irradiance subplots were replicated twice within each temperature. Ten plants of each species were used in each subplot. Date of first open flower [from which days to first open flower (DTF) was calculated (from germination)], flower bud number (all buds $>1$ $\mathrm{mm}$ long), first flower diameter, and leaf number below the first flower were determined when the first floweropened. Aboveground (shoot) biomass was harvested when the first flower opened and dry mass was determined after drying the tissue for $3 \mathrm{~d}$ at $70^{\circ} \mathrm{C}$. Shoot dry mass gain rate was determined by dividing total shoot dry mass by DTF.

\section{Results}

Temperature and DLI each interacted with species to impact flower bud number per plant, first flower diameter, leaf number 
Table 1. Analysis of variance of the impact of species, temperature, and average daily light integral (DLI) on flower bud number at first flower opening (flower bud number), first flower diameter, leaf number below the first flower (leaf number), days to first flower opening (days to first flower) and shoot dry mass gain rate (dry mass gain rate).

\begin{tabular}{lccccc}
\hline $\begin{array}{l}\text { Source of } \\
\text { variation }\end{array}$ & $\begin{array}{r}\text { Flower } \\
\text { bud no. }\end{array}$ & $\begin{array}{c}\text { First flower } \\
\text { diam }\end{array}$ & $\begin{array}{c}\text { Leaf } \\
\text { no. }\end{array}$ & $\begin{array}{c}\text { Days to } \\
\text { first flower }\end{array}$ & $\begin{array}{c}\text { Dry mass } \\
\text { gain rate }\end{array}$ \\
\hline Species (S) & $* * *$ & $* * *$ & $* * *$ & $* * *$ & $* * *$ \\
Temp (T) & $* * *$ & $* * *$ & $*$ & $* * *$ & $* * *$ \\
DLI & $* * *$ & $* * *$ & $* * *$ & $* * *$ & $* * *$ \\
$\mathrm{~S} \times \mathrm{T}$ & $* * *$ & $* * *$ & $* * *$ & $* * *$ & $* * *$ \\
$\mathrm{~S} \times \mathrm{DLI}$ & $* * *$ & $* * *$ & $* * *$ & $* * *$ & $* * *$ \\
$\mathrm{~T} \times \mathrm{DLI}$ & $*$ & $\mathrm{NS}$ & $\mathrm{NS}$ & $*$ & $* * *$ \\
$\mathrm{~S} \times \mathrm{T} \times \mathrm{DLI}$ & $\mathrm{NS}$ & $\mathrm{NS}$ & $\mathrm{NS}$ & $\mathrm{NS}$ & $* * *$ \\
\hline
\end{tabular}

ns, *,**,***Nonsignificant or significant at $P \leq 0.05,0.01$, or 0.001 , respectively.

below the first open flower, DTF, and shoot dry mass gain per day (Table 1). Species, temperature and DLI all interacted to impact shoot dry mass gain rate per day only (Table 1).

Flower bud NUmber Per Plant. High temperature $\left(32{ }^{\circ} \mathrm{C}\right)$ reduced flower bud number per plant of all species (Fig. 1). For example, increasing temperature from 20 to $32{ }^{\circ} \mathrm{C}$ decreased calendula flower bud number per plant, which was 14 at $20^{\circ} \mathrm{C}$ compared to 7 at $32^{\circ} \mathrm{C}\left(10.5 \mathrm{~mol} \cdot \mathrm{m}^{-2} \cdot \mathrm{d}^{-1} \mathrm{DLI} ;\right.$ Fig. 1$)$. The percent reduction in flower bud number per plant at 32 compared to 20 ${ }^{\circ} \mathrm{C}\left(10.5 \mathrm{~mol} \cdot \mathrm{m}^{-2} \cdot \mathrm{d}^{-1} \mathrm{DLI}\right)$ varied from $30 \%$ (impatiens) to $95 \%$ (torenia; Fig. 1).

Increasing DLI from 10.5 to $17.5 \mathrm{~mol} \cdot \mathrm{m}^{-2} \cdot \mathrm{d}^{-1}$ within a temperature treatment increased flower bud number per plant on all species except calendula (Fig. 1). For example, mimulus flower bud number per plant increased from 19 to 32 buds as DLI increased from 10.5 to $17.5 \mathrm{~mol} \cdot \mathrm{m}^{-2} \cdot \mathrm{d}^{-1}$ at $20{ }^{\circ} \mathrm{C}$ (Fig. 1). Further increasing DLI from 17.5 to $21.8 \mathrm{~mol} \cdot \mathrm{m}^{-2} \cdot \mathrm{d}^{-1}$ did not increase flower bud number of any species at either temperature.

FirST FLOWER DIAMETER. Temperature and DLI affected first flower diameter of all species (Fig. 2) except snapdragon. Snapdragon first flower diameter was $37 \mathrm{~mm}$, regardless of temperature or DLI (data not shown). Calendula first flower diameter was unaffected by DLI at $20^{\circ} \mathrm{C}$, but declined from 41 to $37 \mathrm{~mm}$ as DLI increased from 10.5 to $21.8 \mathrm{~mol} \cdot \mathrm{m}^{-2} \cdot \mathrm{d}^{-1}$ at $32{ }^{\circ} \mathrm{C}$ (Fig. 2). In contrast, impatiens, mimulus, and torenia first flower diameter increased as DLI increased, regardless of temperature (Fig. 2).

LEAF NUMBER BELOW THE FIRST FLOWER. Leaf number below the first flower was greater at 32 than $20^{\circ} \mathrm{C}$ for calendula, impatiens, and torenia, regardless of DLI, and for snapdragon under a DLI of $10.5 \mathrm{~mol} \cdot \mathrm{m}^{-2} \cdot \mathrm{d}^{-1}$ only (Fig. 3). Mimulus leaf number below the first flower was three leaves, regardless of temperature or DLI (data not shown). Increasing DLI decreased leaf number below the first flower of snapdragon and calendula only (Fig. 3).

DAYS TO FIRST OPENFLOWER. The impact of DLI and temperature on DTF varied across species. Increasing DLI from 10.5 to 17.5 $\mathrm{mol} \cdot \mathrm{m}^{-2} \cdot \mathrm{d}^{-1}$ reduced DTF for snapdragon, calendula, mimulus and torenia, regardless of temperature, and reduced impatiens DTF at $32{ }^{\circ} \mathrm{C}$ only (Table 2). Further increasing DLI from 17.5

Fig. 1. Impact of temperature and daily light integral on flower bud number per plant (visible buds $\geq 1 \mathrm{~mm}$ in length) when the first flower opened [flower bud number (FBN)] of Antirrhinum majus 'Rocket Rose', Calendula officinalis 'Calypso Orange', Impatiens wallerana 'Super Elfin White', Mimulus $\times$ hybridus 'Mystic Yellow', and Torenia fournieri 'Clown Burgundy'. Data points are means \pm SE. Lines represent linear regression analysis of the means.
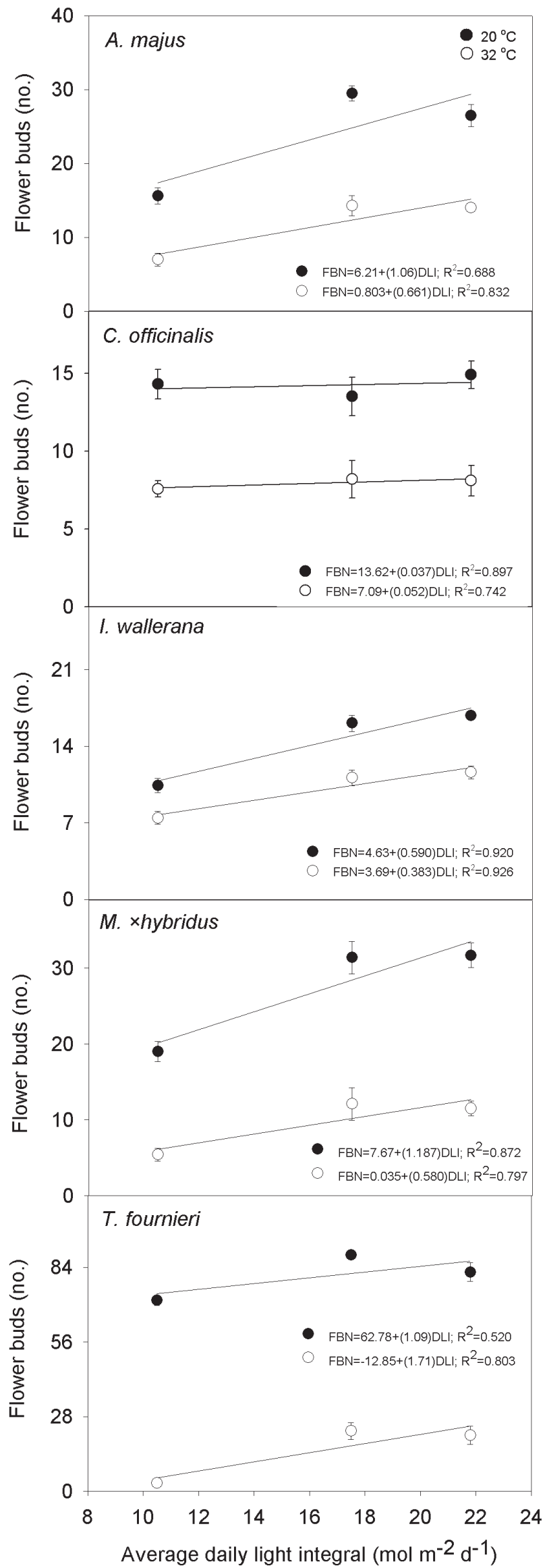


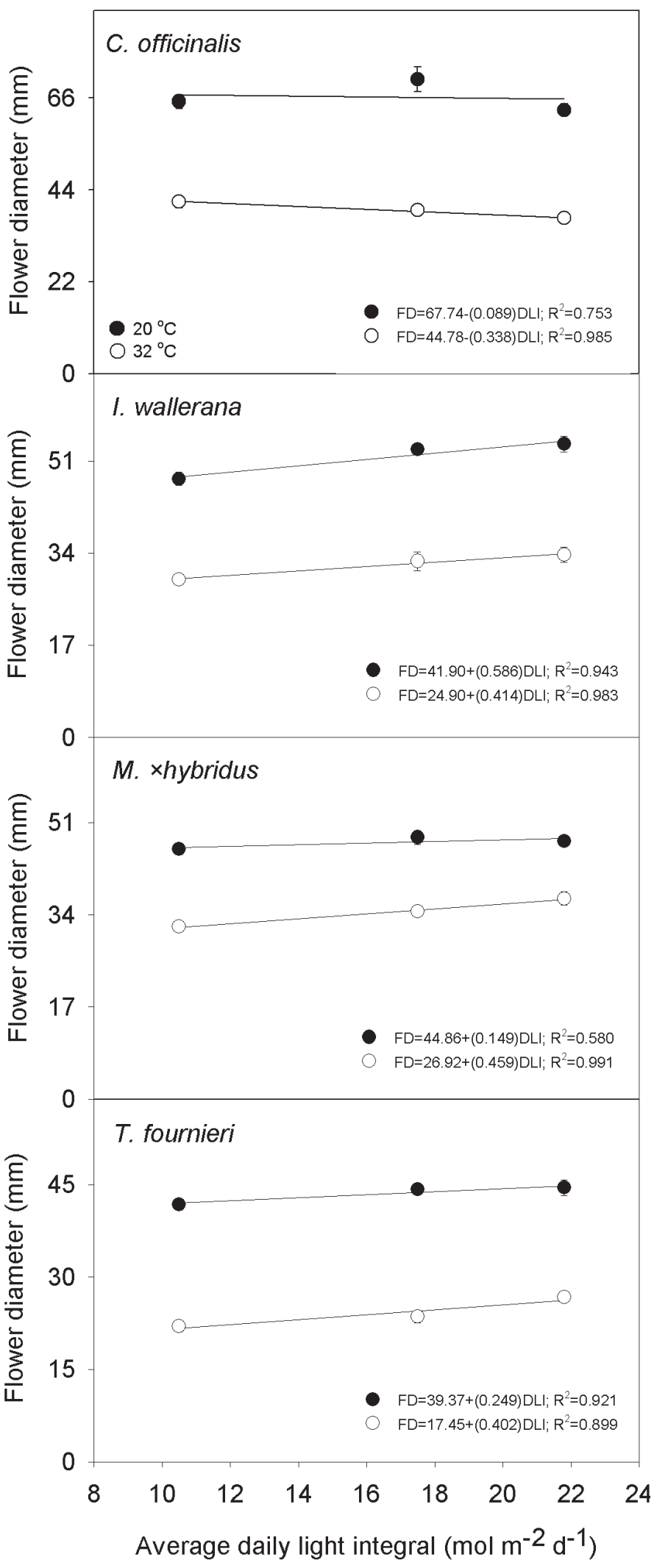

Fig. 2. Impact of temperature and daily light integral on first flower diameter [flower diameter (FD)] of Calendula officinalis 'Calypso Orange', Impatiens wallerana 'Super Elfin White', Mimulus $\times$ hybridus 'Mystic Yellow', and Torenia fournieri 'Clown Burgundy'. Data points are means \pm SE. Lines represent linear regression analysis of the means.

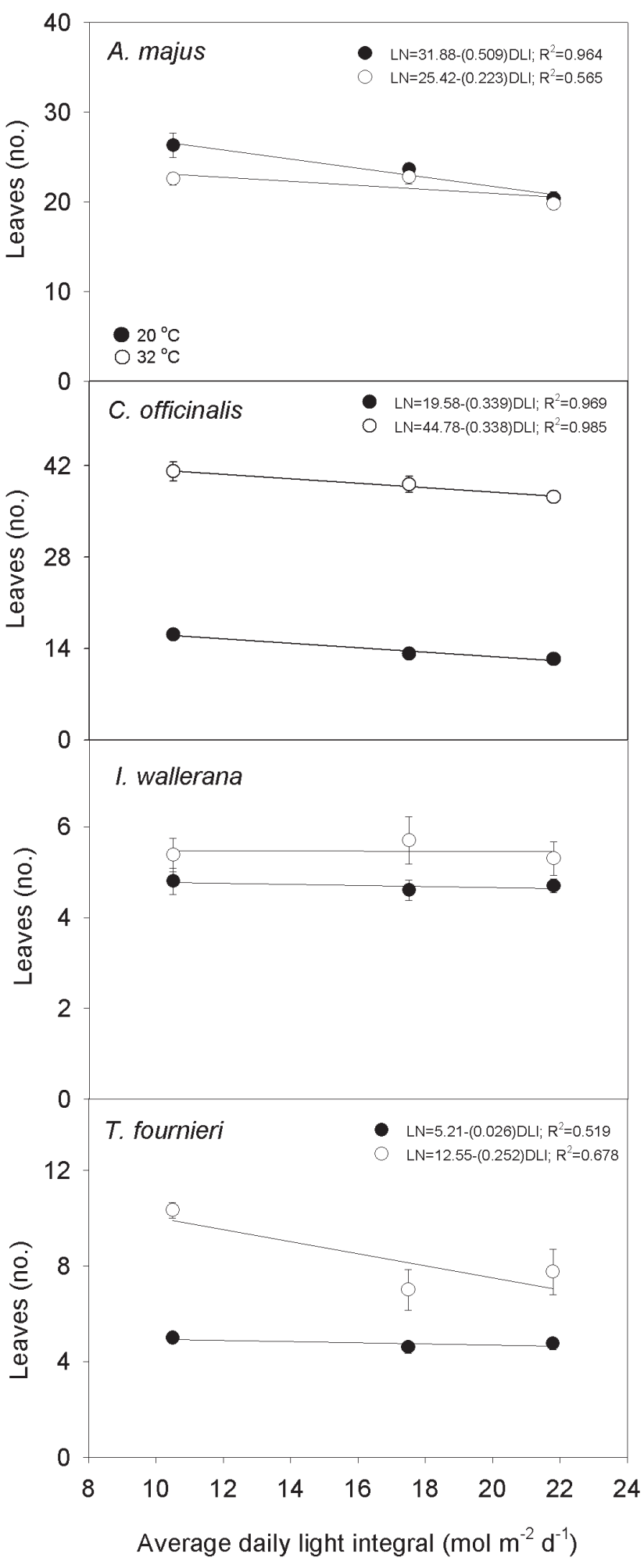

Fig. 3. Impact of temperature and daily light integral on leaf number below the first open flower [leaf number (LN)] of Antirrhinum majus 'Rocket Rose', Calendula officinalis 'Calypso Orange', Impatiens wallerana 'Super Elfin White', and Torenia fournieri 'Clown Burgundy'. Data points are means \pm SE. Lines represent linear regression analysis of the means. 
Table 2. Impact of temperature and average daily light integral on days to first flower and shoot dry mass gain rate of five herbaceous ornamental species. Capital letters represent mean separation across temperature within daily light integral and species. Lowercase letters represent mean separation across daily light integral, within temperature and species. Mean separation was conducted using Tukey's honestly significant difference at $P \leq 0.05$.

\begin{tabular}{|c|c|c|c|c|c|c|c|}
\hline \multirow[b]{2}{*}{ Species } & \multirow{2}{*}{$\begin{array}{c}\text { Temp } \\
\left({ }^{\circ} \mathrm{C}\right)\end{array}$} & \multicolumn{3}{|c|}{ Avg daily light integral $\left(\mathrm{mol} \cdot \mathrm{m}^{-2} \cdot \mathrm{d}^{-1}\right)$} & \multicolumn{3}{|c|}{ Avg daily light integral $\left(\mathrm{mol} \cdot \mathrm{m}^{-2} \cdot \mathrm{d}^{-1}\right)$} \\
\hline & & 10.5 & 17.5 & 21.8 & 10.5 & 17.5 & 21.8 \\
\hline & & -------- & to first $\mathrm{f}$ & ------- & \multicolumn{3}{|c|}{$\begin{array}{l}\text { Shoot dry mass } \\
\text { gain rate }\left(\mathrm{mg} \cdot \mathrm{d}^{-1}\right.\end{array}$} \\
\hline \multirow[t]{2}{*}{ Antirrhinum majus 'Rocket Rose' } & 20 & $62^{z} \mathrm{Ac}$ & $49 \mathrm{Bb}$ & $41 \mathrm{Aa}$ & $77 \mathrm{Ba}$ & $188 \mathrm{Bb}$ & $213 \mathrm{Bb}$ \\
\hline & 32 & $59 \mathrm{Ab}$ & $40 \mathrm{Aa}$ & $38 \mathrm{Aa}$ & $29 \mathrm{Aa}$ & $73 \mathrm{Ab}$ & $97 \mathrm{Ac}$ \\
\hline \multirow[t]{2}{*}{ Calendula officinalis 'Calypso Orange' } & 20 & $42 \mathrm{Ab}$ & $29 \mathrm{Ba}$ & $26 \mathrm{Ba}$ & $97 \mathrm{Ba}$ & $171 \mathrm{Bb}$ & $196 \mathrm{Bc}$ \\
\hline & 32 & $40 \mathrm{Ab}$ & $25 \mathrm{Aa}$ & $20 \mathrm{Aa}$ & $49 \mathrm{Aa}$ & $98 \mathrm{Ab}$ & $97 \mathrm{Ab}$ \\
\hline \multirow[t]{2}{*}{ Impatiens wallerana 'Super Elfin White' } & 20 & $33 \mathrm{Aa}$ & $31 \mathrm{Aa}$ & $30 \mathrm{Aa}$ & $30 \mathrm{Aa}$ & $64 \mathrm{Ab}$ & $102 \mathrm{Bc}$ \\
\hline & 32 & $35 \mathrm{Ab}$ & $32 \mathrm{Aa}$ & $31 \mathrm{Aa}$ & $25 \mathrm{Aa}$ & $68 \mathrm{Ab}$ & $59 \mathrm{Ab}$ \\
\hline \multirow[t]{2}{*}{ Mimulus $\times$ hybridus 'Mystic Yellow' } & 20 & $21 \mathrm{Ab}$ & $19 \mathrm{Aa}$ & $17 \mathrm{Aa}$ & $19 \mathrm{Ba}$ & $49 \mathrm{Bb}$ & $50 \mathrm{Bb}$ \\
\hline & 32 & $23 \mathrm{Ab}$ & $16 \mathrm{Aa}$ & $16 \mathrm{Aa}$ & $7 \mathrm{Aa}$ & $16 \mathrm{Ab}$ & $14 \mathrm{Ab}$ \\
\hline \multirow[t]{2}{*}{ Torenia fournieri 'Clown Burgundy' } & 20 & $58 \mathrm{Ab}$ & $51 \mathrm{Aa}$ & $46 \mathrm{Aa}$ & $89 \mathrm{Aa}$ & $129 \mathrm{Ab}$ & $181 \mathrm{Ac}$ \\
\hline & 32 & $71 \mathrm{Bb}$ & $50 \mathrm{Aa}$ & $47 \mathrm{Aa}$ & $94 \mathrm{Aa}$ & $252 \mathrm{Bb}$ & $290 \mathrm{Bc}$ \\
\hline
\end{tabular}

${ }^{2}$ Numeral represents treatment mean.

to $21.8 \mathrm{~mol} \cdot \mathrm{m}^{-2} \cdot \mathrm{d}^{-1}$ reduced DTF for snapdragon at $20{ }^{\circ} \mathrm{C}$ only. Calendula DTF was lower at 32 than $20^{\circ} \mathrm{C}$ under DLIs of 17.5 and $21.8 \mathrm{~mol} \cdot \mathrm{m}^{-2} \cdot \mathrm{d}^{-1}$ only, while snapdragon DTF was lower at 32 than $20^{\circ} \mathrm{C}$ under a DLI of $17.5 \mathrm{~mol} \cdot \mathrm{m}^{-2} \cdot \mathrm{d}^{-1}$ only (Table 2 ). In contrast, torenia DTF was greater at 32 compared to $20^{\circ} \mathrm{C}$ under a DLI of $10.5 \mathrm{~mol} \cdot \mathrm{m}^{-2} \cdot \mathrm{d}^{-1}$. Temperature did not impact impatiens or mimulus DTF, regardless of DLI (Table 2).

Shoot DRY MASS GaIN RATE. Temperature, DLI, and species interacted to impact shoot dry mass gain rate (Table 2). Snapdragon, calendula, and mimulus shoot dry mass gain rate was greater at 20 than $32^{\circ} \mathrm{C}$, regardless of DLI (Table 2). Shoot dry mass gain rate for impatiens was similar across temperature at 10.5 and $17.5 \mathrm{~mol} \cdot \mathrm{m}^{-2} \cdot \mathrm{d}^{-1}$, but lower at 32 than $20^{\circ} \mathrm{C}(59$ compared to $102 \mathrm{mg} \cdot \mathrm{d}^{-1}$ ) at a DLI of $21.8 \mathrm{~mol} \cdot \mathrm{m}^{-2} \cdot \mathrm{d}^{-1}$ (Table 2). In contrast, shoot dry mass gain rate of torenia was greater at 32 than $20^{\circ} \mathrm{C}$ at DLIs of 17.5 and $21.8 \mathrm{~mol} \cdot \mathrm{m}^{-2} \cdot \mathrm{d}^{-1}$ (Table 2). Torenia shoot dry

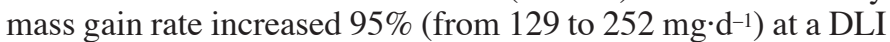
of $17.5 \mathrm{~mol} \cdot \mathrm{m}^{-2} \cdot \mathrm{d}^{-1}$ and $60 \%$ (from 181 to $290 \mathrm{mg} \cdot \mathrm{d}^{-1}$ ) at a DLI of $21.8 \mathrm{~mol} \cdot \mathrm{m}^{-2} \cdot \mathrm{d}^{-1}$ at 32 compared to $20^{\circ} \mathrm{C}$.

\section{Discussion}

Under field conditions, it is difficult to determine whether observed reductions in flowering are due to high temperatures and/or water stress. This experiment examined the responses of five annual herbaceous ornamentals to prolonged elevated temperatures under conditions of adequate water availability with varying DLI. Our results indicate that high temperatures alone reduce flowering (reductions in flower number and diameter) in these five species. Increasing temperature reduced flower bud number of all species, regardless of DLI. Similar reductions in flower bud number as temperature increases occur on Brassica napus L. (canola), B. rapa L. (oilseed rape), and B. juncea (L.) Czernj. \& Cosson (mustard) (Morrison and Stewart, 2002); Campanula carpatica Jacq. (tussock bellflower) 'Deep Blue Clips' and Campanula L. 'Birch Hybrid' (Niu et al., 2001); and Rudbeckia fulgida Ait. (coneflower) 'Goldsturm' (Yuan et al., 1998). For example, Oenothera fruiticosa L. (sundrops) 'Youngii-lapsley' flower bud number decreased from about 170 to fewer than 30 as temperature increased from 15 to $30^{\circ} \mathrm{C}$ (Clough et al., 2001).
Increasing DLI within a temperature treatment increased flower bud number of snapdragon, impatiens, mimulus, and torenia (Fig. 1). Increasing DLI increased flower bud number of several other species, including Hibiscus radiatus (Warner and Erwin, 2003), chrysanthemum 'Resiliance' (Warrington and Norton, 1991), tussock bellflower 'Karl Foerster' (Serek, 1991), and miniature rose 'Rubino' (Mortensen and Moe, 1995). For example, increasing DLI from 9.8 to $19.4 \mathrm{~mol} \cdot \mathrm{m}^{-2} \cdot \mathrm{d}^{-1}$ increased chrysanthemum 'Resiliance' flower number per plant from 3 to 11 flowers (Warrington and Norton, 1991).

The reduced flower diameter under elevated temperatures observed here for several species is consistent with results for other species, including sundrops (Clough et al., 2001), pansy (Niu et al., 2000), Leucanthemum ×superbum Bergman ex. J. Ingram (shasta daisy) (Yuan et al., 1998), and Campanula carpatica (Niu et al., 2001). Pansy 'Universal Violet' flower area decreased from 25.8 to $10.1 \mathrm{~cm}^{2}$ as average daily temperature increased from 15 to $25^{\circ} \mathrm{C}$ (Pearson et al., 1995).

Flowering of snapdragon, calendula, and torenia was delayed developmentally (as evidenced by increased leaf number below the first flower) at 32 compared to $20{ }^{\circ} \mathrm{C}$. The increase in leaf number below the first flower observed for these species is consistent with results for other species. For example, increasing day/night temperature (9-h day/15-h night) from $22 / 18{ }^{\circ} \mathrm{C}$ to $30 / 26^{\circ} \mathrm{C}$ increased chrysanthemum 'Orange Bowl' leaf number below the first flower from 16 to 20 leaves (Whealy et al., 1987). Similarly, increasing temperature from 20 to $25^{\circ} \mathrm{C}$ increased leaf number below the first flower of Hibiscus asper Hook f. from 7 to 23 leaves and of Hibiscus physaloides Guill. from 15 to 24 leaves (Warner and Erwin, 2001b). Increasing temperature from 20 to $30{ }^{\circ} \mathrm{C}$ increased chrysanthemum 'Bright Golden Anne' days to visible flower bud from 33 to $48 \mathrm{~d}$ and increased total DTF from 78 to 137 d (Karlsson et al., 1989). Yeh and Lin (2003) found that the degree of heat-induced delay in flowering across chrysanthemum cultivars correlated with thermostability of cell membranes of young vegetative plants, as determined by measuring electrolyte leakage. Electrolyte leakage may be a useful assay for breeders to screen large populations for heat tolerance of flowering early in development.

Shoot dry mass gain rate of all species presented here increased 
as DLI increased from 10.5 to $17.5 \mathrm{~mol} \cdot \mathrm{m}^{-2} \cdot \mathrm{d}^{-1}$, consistent with results for other species, including lettuce (Kitaya et al., 1998) and chrysanthemum (Karlsson and Heins, 1992). For example, chrysanthemum 'Bright Golden Anne' dry mass at flowering increased from 3.6 to $15.3 \mathrm{~g}$ as DLI increased from 1.8 to 21.6 $\mathrm{mol} \cdot \mathrm{m}^{-2} \cdot \mathrm{d}^{-1}$ at $20{ }^{\circ} \mathrm{C}$ (Karlsson and Heins, 1992).

Increasing temperature reduced flowering of all species, but differentially impacted shoot dry mass gain across species. Increasing temperature from 20 to $32^{\circ} \mathrm{C}$ under a DLI of $21.8 \mathrm{~mol} \cdot \mathrm{m}^{-2} \cdot \mathrm{d}^{-1}$ reduced shoot dry mass gain rate for all species except torenia (Table 2). Reductions in plant dry mass at elevated temperatures were observed previously for a number of species. For example, Platycodon grandiflorus (Jacq.) A. DC. (balloon flower) 'Astra Blue' dry mass at flowering decreased from 5.1 to $1.1 \mathrm{~g}$ as temperature increased from 13.7 to $28.9^{\circ} \mathrm{C}$ (Park et al., 1998). Pansy 'Delta Yellow Blotch' flower bud and shoot dry mass at flowering decreased as average daily temperature increased from 15 to 25 ${ }^{\circ} \mathrm{C}$ under DLIs of 10.6 or $15.6 \mathrm{~mol} \cdot \mathrm{m}^{-2 \cdot} \cdot \mathrm{d}^{-1}$ (Niu et al., 2000). The reductions in dry mass gain rate observed herein are consistent with observed reductions in net photosynthetic rate following high temperature exposures. For example, photosynthetic rates of five Betula L. species declined as temperature increased above $25^{\circ} \mathrm{C}$ (Ranney and Peet, 1994). Similarly, photosynthetic rates of four herbaceous ornamentals [pansy 'Scarlet Bronze', geranium 'Pinto Violet', Tagetes patula L. (french marigold) 'Antigua Orange', and Petunia xhybrida Hort. Vilm.-Andr. (petunia) 'Dreams Red'] decreased as temperature increased from 15 to $38^{\circ} \mathrm{C}$ (van Iersel, 2003).

Torenia may serve as a useful model for studying reduced flowering associated with high temperatures without the confounding effects of reduced growth rate under high temperature. In contrast to other species studied here, high temperature-induced flowering reductions in torenia were not correlated with dry mass gain reductions. More torenia cultivars must be screened to determine the range of variation that exists for high temperature effects on growth and flowering. Torenia may also be useful to study interactions between temperature and DLI on flower initiation, as torenia leaf number below the first flower was unaffected by DLI at $20{ }^{\circ} \mathrm{C}$, but decreasing DLI from 21.8 to $10.5 \mathrm{~mol} \cdot \mathrm{m}^{-2} \cdot \mathrm{d}^{-1}$ increased leaf number below the first flower at $32{ }^{\circ} \mathrm{C}$ (Fig. 3). In contrast, calendula may be useful for studying temperature effects on flower initiation independent of DLI, as increasing temperature from 20 to $32^{\circ} \mathrm{C}$ nearly tripled the number of leaves formed below the first flower, regardless of DLI.

It is common for greenhouse growers to cover crops with screening materials that reduce irradiance from $33 \%$ to $80 \%$ during hot days to help reduce greenhouse air and plant temperature. In the present study, we observed that snapdragon, calendula, and mimulus shoot dry mass gain rates were dramatically reduced under high temperature $\left(32{ }^{\circ} \mathrm{C}\right)$, low light $\left(10.5 \mathrm{~mol} \cdot \mathrm{m}^{-2} \cdot \mathrm{d}^{-1}\right.$; Table 2) conditions, and torenia flowering was almost completely inhibited under these conditions. Decreasing DLI from 21.8 to $10.5 \mathrm{~mol} \cdot \mathrm{m}^{-2} \cdot \mathrm{d}^{-1}$ at $32{ }^{\circ} \mathrm{C}$ also delayed flowering (i.e., increased leaf number below the first flower) in snapdragon, calendula, and torenia (Fig. 3) and decreased flower bud number of all species except calendula (Fig. 2). Instead of covering crops with lightreduction materials, growers may be better served by investing in greater greenhouse cooling capacity through vents, fans, and/or evaporative cooling pads to increase plant quality during high irradiance and temperature periods of the year.

\section{Literature Cited}

Abdul-Baki, A.A. 1991. Tolerance of tomato cultivars and selected germplasm to heat stress. J. Amer. Soc. Hort. Sci. 116:1113-1116.

Aloni, B., T. Pashkar, and L. Karni. 1991. Partitioning on [ $\left.{ }^{14} \mathrm{C}\right]$ sucrose and acid invertase activity in reproductive organs of pepper plants in relation to their abscission under heat stress. Ann. Bot. 67:371-377.

Armitage, A.M., W.H. Carlson, and J.A. Flore. 1981. The effect of temperature and quantum flux density on the morphology, physiology, and flowering of hybrid geraniums. J. Amer. Soc. Hort. Sci. 106:643-647.

Bjorkman, T. and K.J. Pearson. 1998. High temperature arrest of inflorescence development in broccoli (Brassica oleracea var. italica L.). J. Expt. Bot. 49:101-106.

Calvert, A. 1969. Studies on the post-initiation development of flower buds of tomato (Lycopersicon esculentum). J. Hort. Sci. 44:117-126

Carr, S.M. and V.F. Irish. 1997. Floral homeotic gene expression defines developmental arrest stages in Brassica oleracea vars. botrytis and italica. Planta 201:179-188.

Clough, E.A., A.C. Cameron, R.D. Heins, and W.H. Carlson. 2001. Growth and development of Oenothera fruiticosa is influenced by vernalization duration, photoperiod, forcing temperature, and plant growth regulators. J. Amer. Soc. Hort. Sci. 126:269-274.

de Lint, P.J.A.L. and G. Heij. 1987. Effects of day and night temperature on growth and flowering of chrysanthumum. Acta Hort. 197:53-61.

Erwin, J., R. Heins, R. Berghage, and B. Kovanda. 1990. Temperature effects Schlumbergera truncata 'Madisto' flower initiation. Acta Hort. 272:97-101.

Erwin, J.E. and R.M. Warner. 2002. Determination of photoperiodic response group and effect of supplemental irradiance on flowering of several annual bedding plant species. Acta Hort. 580:95-99.

Fierro, A., N. Tremblay, and A. Gosselin. 1994. Supplemental carbon dioxide and light improved tomato and pepper seedling growth and yield. HortScience 29:152-154.

Karlsson, M.G. and R.D. Heins. 1992. Chrysanthemum dry matter partitioning patterns along irradiance and temperature gradients. Can. J. Plant Sci. 72:307-316.

Karlsson, M.G., R.D. Heins, J.E. Erwin, and R.D. Berghage. 1989. Development rate during four phases of chrysanthemum growth as determined by preceding and prevailing temperatures. J. Amer. Soc. Hort. Sci. 114:234-240.

Kitaya, Y., G. Niu, T. Kozai, and M. Ohashi. 1998. Photosynthetic photon flux, photoperiod, and $\mathrm{CO}_{2}$ concentration affect growth and morphology of lettuce plug transplants. HortScience 33:988-991.

Monterosso, V.A. and C. Wien. 1990. Flower and pod abscission due to heat stress in beans. J. Amer. Soc. Hort. Sci. 115:631-634.

Morrison, M.J. and D.W. Stewart. 2002. Heat stress during flowering in summer Brassica. Crop Sci. 42:797-803.

Mortensen, L.M. and R. Moe. 1995. Effects of temperature, carbon dioxide concentration, day length and photon flux density on growth, morphogenesis and flowering of miniature roses. Acta Hort. 378:63-70.

Niu, G., R.D. Heins, A. Cameron, and W. Carlson. 2001. Temperature and daily light integral influence plant quality and flower development of Campanula carpatica 'Blue Clips', 'Deep Blue Clips', and Campanula 'Birch Hybrid'. HortScience 36:664-668.

Niu, G., R.D. Heins, A.C. Cameron, and W.H. Carlson. 2000. Day and night temperatures, daily light integral, and $\mathrm{CO}_{2}$ enrichment affect growth and flower development of pansy (Viola $\times$ wittrockiana). J. Amer. Soc. Hort. Sci. 125:436-441.

Park, B.H., N. Oliveira, and S. Pearson. 1998. Temperature affects growth and flowering of the ballon flower [Platycodon grandiflorus (Jacq.) A. DC. cv. Astra Blue]. HortScience 33:233-236.

Pearson, S., A. Parker, S.R. Adams, P. Hadley, and D.R. May. 1995. The effects of temperature on the flower size of pansy (Viola $\times$ wittrockiana Gams.). J. Hort. Sci. 70:183-190. 
Pressman, E., M.M. Peet, and D.M. Pharr. 2002. The effects of heat stress on tomato pollen characteristics is associated with changes in carbohydrate concentration in the developing anthers. Ann. Bot. 90:631-636.

Ranney, T.G. and M.M. Peet. 1994. Heat tolerance of five taxa of birch (Betula): Physiological responses to supraoptimal leaf temperatures. J. Amer. Soc. Hort. Sci. 119:243-248.

Reese, C.L. and J.E. Erwin. 1997. The effect of day/night temperature on Pharbitis nil Chois. flowering. HortScience 32:1046-1048.

Rylski, I. 1986. Pepper (Capsicum), p. 341-354. In: S.P. Monselise (ed.). Handbook of fruit set and development. CRC Press, Boca Raton, Fla.

Schwabe, W.W. 1985. Kalanchoe blossfeldiana, p. 217-235. In: A.H. Halevy (ed.). Handbook of flowering, vol. III. CRC Press, Boca Raton, Fla.

Serek, M. 1991. Effects of pre-harvest supplementary irradiance on decorative value and ethylene evolution of Campanula carpatica 'Karl Foerster' flowers. Scientia Hort. 48:341-347.

van Iersel, M.W. 2003. Short-term temperature change affects the carbon exchange characteristics and growth of four bedding plant species. J. Amer. Soc. Hort. Sci. 128:100-106.

Warner, R.M. and J.E. Erwin. 2001a. Effect of high-temperature stress on flower number per inflorescence of 11 Lycopersicon esculentum Mill. genotypes. HortScience 36:508. (Abstr.)

Warner, R.M. and J.E. Erwin. 2001b. Variation in floral induction requirements of Hibiscus sp. J. Amer. Soc. Hort. Sci. 126:262-268.

Warner, R.M. and J.E. Erwin. 2003. Effect of photoperiod and daily light integral on flowering of five Hibiscus sp. Scientia Hort. 97:341-351.

Warrington, I.J. and R.A. Norton. 1991. An evaluation of plant growth and development under various daily quantum integrals. J. Amer. Soc. Hort. Sci. 116:544-551.

Whealy, C.A., T.A. Nell, J.E. Barrett, and R.A. Larson. 1987. High temperature effects on growth and floral development in chrysanthemum. J. Amer. Soc. Hort. Sci. 112:464-468.

Wilkins, H.F., W.E. Healy, and K.L. Grueber. 1990. Temperature regime at various stages of production influences growth and flowering of Dendranthema $\times$ grandiflorum. J. Amer. Soc. Hort. Sci. 115:732-736.

Yeh, D.M. and H.F. Lin. 2003. Thermostability of cell membranes as a measure of heat tolerance and relationship to flowering delay in chrysanthemum. J. Amer. Soc. Hort. Sci. 128:656-660.

Yuan, M., W.H. Carlson, R.D. Heins, and A.C. Cameron. 1998. Effect of forcing temperature on time to flower of Coreopsis grandiflora, Gaillardia $\times$ grandiflora, Leucanthemum $\times$ superbum, and Rudbeckia fulgida. HortScience 33:663-667. 